\title{
Review Article \\ Review of Recent Progress in Dye-Sensitized Solar Cells
}

\author{
Fan-Tai Kong, Song-Yuan Dai, and Kong-Jia Wang \\ Division of Solar Energy Materials and Engineering, Institute of Plasma Physics, Chinese Academy of Sciences, \\ Hefei, Anhui 230031, China
}

Received 27 March 2007; Accepted 25 June 2007

Recommended by Armin G. Aberle

We introduced the structure and the principle of dye-sensitized solar cell (DSC). The latest results about the critical technology and the industrialization research on dye-sensitized solar cells were reviewed. The development of key components, including nanoporous semiconductor films, dye sensitizers, redox electrolyte, counter electrode, and conducting substrate in dye-sensitized solar cells was reviewed in detail. The developing progress and prospect of dye-sensitized solar cells from small cells in the laboratory to industrialization large-scale production were reviewed. At last, the future development of DSC was prospective for the tendency of dye-sensitized solar cells.

Copyright (C) 2007 Fan-Tai Kong et al. This is an open access article distributed under the Creative Commons Attribution License, which permits unrestricted use, distribution, and reproduction in any medium, provided the original work is properly cited.

\section{INTRODUCTION}

Since Professor M. Grätzel in EPFL introduced the nanoporous films into dye-derived wideband semiconductor research and made the breakthrough in the photoelectric conversion efficiency of dye-sensitized solar cells (DSCs), academic and commercial interests have been paid on DSCs for their high efficiency, their potential low-cost and simple assemble technology, especially in the past 6 years since Grätzel and his group team at EPFL were able to demonstrate the first $10 \%$ efficient cells certified by NREL in USA [1-18]. Dye-derivatized mesoporous titania film is one of the key components for high efficiency in such cells. They use bis(bipyridyl) $\mathrm{Ru}$ (II) complexes cis-di(isothiocyanato)bis(2,2' -bipyridyl4,4'-dicarboxylate)ruthenium(II), known as the N3 dye, in conjunction with the nanocrystalline colloidal $\mathrm{TiO}_{2}$ films and $\mathrm{I}_{3}^{-} / \mathrm{I}^{-}$solution in an organic volatile solvent mixture, to convert $10 \%$ of AM 1.5 solar radiation into electrical energy. However, the main drawback of the N3 dye is the lack of light absorption in the red region of the visible spectrum. Carboxylated terpyridyl complexes of tris-thiocyanato $\mathrm{Ru}(\mathrm{II})$, known as the black dye, display outstanding properties as a charge-transfer sensitizer and the first certified efficiency of the solar cells that based is over $10 \%$. In recent years, great developments have been made for both the academic research and the industrial research. This paper reviewed the latest developing progress of dye-sensitized solar cells.

\section{STRUCTURE AND OPERATING PRINCIPLE OF DYE-SENSITIZED SOLAR CELLS}

Dye-sensitized solar cell is composed of nanocrystalline semiconductor oxide film electrode, dye sensitizers, electrolytes, counter electrode and transparent conducting substrate. Typically, dye-derived nanocrystalline titania films were used as photoanode, platinized counter electrode, filled with electrolyte solution of $\mathrm{I}_{3}{ }^{-} / \mathrm{I}^{-}$in organic solvent, then the sandwiched solar cells are formed. The operating mechanism of the solar cells is shown in Figure 1. Under the irradiation of sunlight, the dye molecular became photo-excited and ultrafastly injected an electron into the conduction band of the semiconductor electrode, then the original state of the dye is subsequently restored by electron donation from the electrolyte, usually the solution of an organic solvent or ionic liquid solvent containing the $\mathrm{I}_{3}{ }^{-} / \mathrm{I}^{-}$redox system. The regeneration of the sensitizer by iodide intercepts the recapture of the conduction band electron by the oxidized dye. The iodide is regenerated, in turn, by reduction of triiodide at the counter electrode, the circuit being completed through the external load. The voltage generated under illumination corresponds to the difference between the Fermi level of the electron in the semiconductor electrode and the redox potential of the electrolyte. Overall, electric power is generated without permanent chemical transformation. Along with these processes, electrons in the conduction band of semiconductor may be recombined with the oxided dye sensitizers or electron acceptor species in the electrolyte solution. 


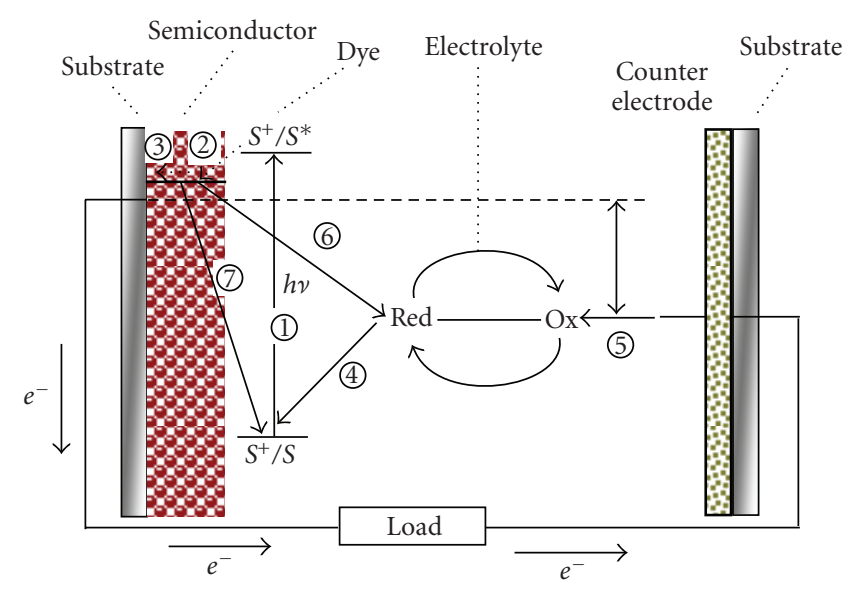

FIGURE 1: Structure and operating principle of dye-sensitized solar cells.

When it comes to solid-state dye-sensitized solar cells, the electrolyte solution is replaced by a wide band gap inorganic semiconductor of p-type polarity, such as CuI or CuSCN, or a hole-transmitting solid, for example, an amorphous organic arylamine and its derivatives. The excited dye injects electrons into the $n$-type oxide, and it is regenerated by hole injection in the p-type material. In recent years, organic solvent electrolyte containing $\mathrm{I}_{3}{ }^{-} / \mathrm{I}^{-}$redox couple was also considered as the transport material. Then the operating principle of DSC based on liquid electrolyte is in corresponding with that of solid-state DSC.

\section{DSC MATERIALS}

\subsection{Nanocrystalline semiconductor film electrode}

Semiconductor oxides used in dye-sensitized solar cell include $\mathrm{TiO}_{2}, \mathrm{ZnO}, \mathrm{SnO}_{2}, \mathrm{Nb}_{2} \mathrm{O}_{5}$, and so forth, which serve as the carrier for the monolayers of the sensitizer using their huge surface and the medium of electron transfer to the conducting substrate. Due to low-cost price, abundance in the market, nontoxicity, and biocompatiblity, and as it is also used widely in health care products as well as in paints, $\mathrm{TiO}_{2}$ becomes the best choice in semiconductor till now. Titanium dioxide films are covered on the conducting substrate such as conducting glass, metal foil, and flexible polymer film. The two selected deposition processes, so-called doctor-blading and screen-printing, are widely used to prepare the nanocrystalline $\mathrm{TiO}_{2}$ films by spreading a viscous dispersion of colloidal $\mathrm{TiO}_{2}$ particles on a conducting glass support before sintering at high temperature. Two methods of preparation of colloidal $\mathrm{TiO}_{2}$ dispersions were typically employed [2]. Method A follows the sol-gel procedure of titanate described by Grätzel et al. with the autoclaving being performed at $200^{\circ} \mathrm{C} \sim 250^{\circ} \mathrm{C}$. After the colloid is spread on the conducting glass support and calcined, a few monolayers of $\mathrm{TiO}_{2}$ are electrodeposited onto the colloidal $\mathrm{TiO}_{2}$ film from an aqueous $\mathrm{Ti}(\mathrm{III})$ solution or treatment with titanium tetrachloride aqueous solution followed by renewed

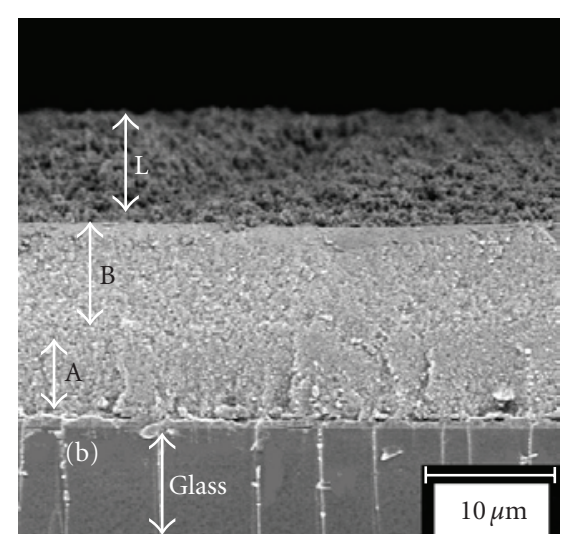

FIGURE 2: FE-SEM cross-section micrographs of $\mathrm{TiO}_{2}$ films photoelectrode; the thickness of A (compact layer), B (nanoporous layer), $\mathrm{L}$ (scattering layer) is $5 \mu \mathrm{m}, 8 \mu \mathrm{m}, 5 \mu \mathrm{m}$ with average particle size of $16 \mathrm{~nm}, 25 \mathrm{~nm}, 300 \mathrm{~nm}$, respectively.

annealing at $450^{\circ} \mathrm{C} \sim 550^{\circ} \mathrm{C}$. This treatment was found to improve significantly the short-circuit photocurrent $\left(J_{\text {sc }}\right)$ as well as the open-circuit voltage $\left(V_{\text {oc }}\right)$ of the solar cell. The second method for preparation of nanocrystalline films (Method B) employs commercial $\mathrm{TiO}_{2}$ (P25, Degussa AG, Germany). Electron microscopy shows the mean size of primary particles to be about $25 \mathrm{~nm}$. In order to break the aggregates into separate particles, the P25 powder is ground in a porcelain mortar with a small amount of water containing acetylacetone or other stabilizers such as acids, bases, or $\mathrm{TiO}_{2}$ chelating agents to prevent reaggregation of the particles. After being dispersed by the high shear forces in the viscous paste, the powder was diluted by slow addition of water under continued grinding. Finally, a detergent, Triton X-100 or ethyl cellulose, was added to facilitate the spreading of the colloid on the substrate.

In the production of large-scale dye-sensitized solar cell modules in our group, the multilayer microstructure of the semiconductor nanocrystalline $\mathrm{TiO}_{2}$ films is optimized [18]. $\mathrm{TiO}_{2}$ photoelectrodes with three different layers (Figure 2), including layers of small pore-size films, larger pore-size films, and light-scattering particles on the conducting glass with the desirable thickness are being employed in large-area dye-sensitized solar cells and modules and contributed to high efficiency of DSC and DSC modules.

To make DSC a commercially competitive technology in the market for flexible solar cells, a new method that permits a film being prepared on flexible organic substrate is needed for purposes of flexibility, weight, and overall device thickness. However, the traditional methods being mentioned above are challenged while using DSC being based on organic flexible substrate. Especially, the polymer substrate is not suitable for preparing electrodes by sintering in high temperature of $450^{\circ} \mathrm{C} \sim 550^{\circ} \mathrm{C}[1-4,19]$. Recently, some methods for preparing semiconductor films on a flexible substrate such as low-temperature annealing at the temperature below $150^{\circ} \mathrm{C}[20,21]$ and a compressing method $[22,23]$ to achieve electrically connected $\mathrm{TiO}_{2}$ network have been reported. Pichot et al. [20] reported the preparation 
of nanocrystalline $\mathrm{TiO}_{2}$ electrode without any organic surfactant by sintering at $100^{\circ} \mathrm{C}$ and the conversion efficiency of the solar cells is $1.2 \%$. Hagfeldt et al. [23] demonstrated a mechanically compressed nanostructured $\mathrm{TiO}_{2}$ layer on a plastic film yielding a fill factor of $47 \%$ and a conversion efficiency of 3.0\%. Miyasaka et al. [24, 25] obtained a fill factor of $61 \%$ and the high conversion efficiency up to $4.1 \%$ with an electrophoretic deposited $\mathrm{TiO}_{2}$ layer following a chemical treatment and a thermal treatment of $150^{\circ} \mathrm{C}$ for interconnecting $\mathrm{TiO}_{2}$ particles. Dürr et al. [26] reported the so-called liftoff technique, in which pre-sintered porous layers on conducting glasses substrate can be transferred to an arbitrary flexible substrate, and the original electrical properties of the transferred porous layers are maintained. They obtained a conversion efficiency of 5.8\% with flexible PET (polyethylene terephthalate) substrates under AM1.5 irradiation $\left(100 \mathrm{~mW} \cdot \mathrm{cm}^{-2}\right)$. This method is too complicate for commercial application. Kijitori et al. [17, 27] prepared binder-free coating paste by using $\mathrm{TiO}_{2}$ sol in acidic aqueous solution as the interconnection agent, and coated the paste on ITO/polyethylene naphthalate (ITO/PEN) film by doctorblade method followed by drying at $150^{\circ} \mathrm{C}$ to obtain $\mathrm{TiO}_{2}$ photoanode. The conversion efficiency of the plastic based DSC is large than 6\%. Grätzel group [28] developed the highefficiency (7.2\%) flexible solar cells based on a Ti-metal foil substrate for photoanode and a Pt-electrodeposited counter electrode on ITO-PEN, which is the highest efficiency for flexible DSC.

Nanocrystalline semiconductor films adsorbed a large amount of dye molecules and increased the harvesting efficiency of solar energy. However, the huge surface area also increases the recombination between electrons in the conduction band of semiconductor oxides and the electron acceptor in the electrolyte. In recent years, increasing interesting in DSC is addressing the use of more sophisticated device architectures in order to reduce interfacial recombination losses. Examples include the use of composite metal oxides as the semiconductor with different band gaps, for example, $\mathrm{Nb}_{2} \mathrm{O}_{5}, \mathrm{ZnO}$, the incorporation of spacer units between the oxidized dye and the $\mathrm{TiO}_{2}$ surface, and surface passivation by coating of semiconductor oxides with high conduction band edge or electrodeposition of insulating polymers. One particularly attractive approach involves the coating of the nanocrystalline metal oxide film with a thin overcoat of another metal oxide with a higher conduction band edge, as illustrated in Figure 3, with the aim of increasing the physical separation of injected electrons from the oxidized dye redox couple, thereby retarding the recombination reactions. When the surface of the $\mathrm{TiO}_{2}$ nanocrystalline electrode was coated with a thin layer semiconductor oxides, such as $\mathrm{ZnO}$, $\mathrm{Nb}_{2} \mathrm{O}_{5}, \mathrm{SrO}, \mathrm{SrTiO}_{3}$, the conversion efficiency of based DSC increased dramatically. After coating of $\mathrm{ZnO}$ and $\mathrm{Nb}_{2} \mathrm{O}_{5}$, the electron density of the conduction band of $\mathrm{TiO}_{2}$ increase with the reduction of charge recombination due to the coreshell barrier. As a result, the open-circuit voltage $\left(V_{\text {oc }}\right)$ and conversion efficiency of the solar cells that based were improved. However, the influence of the introduction of insulating layer on the conversion efficiency of based DSC was still under discussion. Lee [29], Jung [30], and Yum [31]

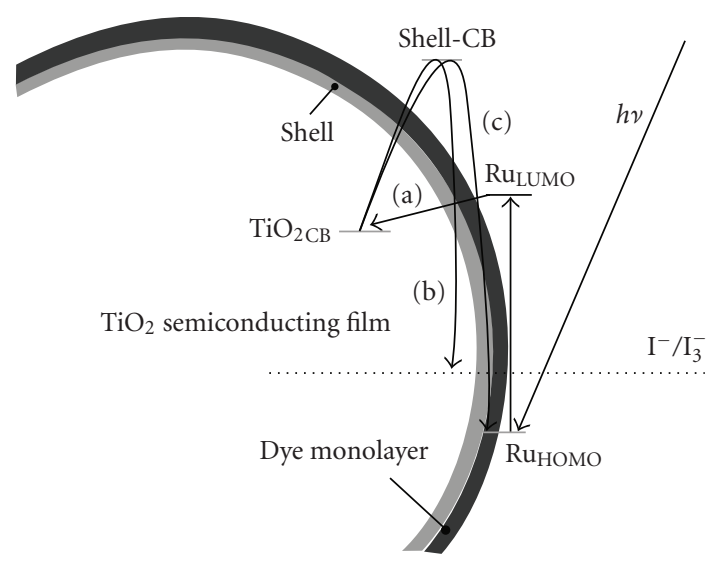

FIgURE 3: Diagrammatic sketch $\mathrm{TiO}_{2}$ coated with high-conductionband-edge semiconductor or insulating layer. (a) Injection of electrons into the conduction band of $\mathrm{TiO}_{2}$ films. (b) Combination of electrons between electron and triiodide in the electrolyte. (c) Charge recombination between electrons of $\mathrm{TiO}_{2}$ films and oxided dye.

adopted $\mathrm{CaCO}_{3}, \mathrm{MgO}$, and metal ( $\left.\mathrm{Mg}, \mathrm{Zn}, \mathrm{Al}, \mathrm{La}\right)$ hydroxide as the insulating barrier for nanometer $\mathrm{TiO}_{2}$ electrodes, respectively; and the introduction of insulating layer have increased the absorbing amount of the dye molecules and improved short-circuit current density $\left(J_{\mathrm{sc}}\right)$, open-circuit voltage, fill factor $(F F)$, and photoelectric conversion efficiency $(\eta)$ of the solar cells. Durrant and so forth [32-35] found that the conversion efficiency of solar cells based $\mathrm{Al}_{2} \mathrm{O}_{3}, \mathrm{ZrO}_{2}$, or $\mathrm{SiO}_{2}$ covered $\mathrm{TiO}_{2}$ electrodes were improved obviously or just kept equal. Kay et al. [36] found the similar results for $\mathrm{ZnO}, \mathrm{TiO}_{2}, \mathrm{Al}_{2} \mathrm{O}_{3}, \mathrm{MgO}$ coated $\mathrm{SnO}_{2}$ electrodes. However, when it came to the $\mathrm{TiO}_{2}$ electrode coated with $\mathrm{Al}_{2} \mathrm{O}_{3}, \mathrm{MgO}$ and $\mathrm{Y}_{2} \mathrm{O}_{3}$, the $V_{\mathrm{oc}}$ and $F F$ of the solar cells that based rise, while the short-circuit current density droped sharply, which led to the reduction of overall photoelectric conversion efficiency of the solar cells.

The preparation of high-efficiency semiconductor electrode is of significant importance for the improvement of the efficiency and the commercial application of dye-sensitized solar cells. To prepare the semiconductor film electrode with uniform-size high-special surface area, and the porous structure whose direction is perpendicular to the conducting substrate is one of the focuses of present research [37]. In order to improve the portability of DSC and scope of application, more and more researchers were interested in the preparation methods for nanocrystalline semiconductor film electrode on flexible substrate.

\subsection{Dye sensitizer}

Dye sensitizers serve as the solar energy absorber in DSC, whose proprieties will have much effect on the light harvesting efficiency and the overall photoelectric conversion efficiency. The ideal sensitizer for dye-sensitized solar cells should absorb all light below a threshold wavelength of about $920 \mathrm{~nm}$. In addition, it should be firmly grafted to 
the semiconductor oxide surface and inject electrons to the conduction band with a quantum yield of unity. Its redox potential should be sufficiently high that it can be regenerated rapidly via electron donation from the electrolyte or a hole conductor. Finally, it should be stable enough to sustain at least $10^{8}$ redox turnovers under illumination corresponding to about 20 years of exposure to natural light [38]. The best photovoltaic performance in terms of both conversion yield and long-term stability has so far been achieved with polypyridyl complexes of ruthenium and osmium. The sensitizers used in DSC were divided into two types: organic dye and inorganic dye according to the structure. Inorganic dye includes metal complex, such as polypyridyl complexes of ruthenium and osmium, metal porphyrin, phthalocyanine and inorganic quantum dots, while organic dye includes natural organic dye and synthetical organic dye.

Compared with organic dye, inorganic complexes dye has high thermal stability and chemical stability. Among these complexes, Polypyridyl ruthenium sensitizers were widely used and investigated for its high stability and outstanding redox properties and good responding for natural visible sunlight. The sensitizers anchored on the surface of semiconductor film electrode with carboxylate group or phosphonate group, which enable the electron injection into the conduction band of the semiconductor. Polypyridyl ruthenium dye may be divided into carboxylate polypyridyl ruthenium dye, phosphonate ruthenium dye, and polynuclear bipyridyl ruthenium dye. The difference between the first two types of sensitizers lies in the adsorption group. The first two types of sensitizers differ from the last type of sensitizer in the number of metal center. The carboxylate polypyridyl ruthenium dye is in level structure, which enables the electron injection into the conduction band of the semiconductor quantitatively. Among these sensitizers, N3 and its tetrabutylammonium salt N719, black dye showed the unmatched performance. The efficiency records of more than $11 \%$ for dye sensitized solar cells are based on N719 or black dye. In recent years, amphiphilic ruthenium dye represented by Z907 and high-molar-extinction-coefficient ruthenium sensitizers represented by K19 became the focuses of the research about carboxylate polypyridyl ruthenium sensitizers. Figure 4 and Table 1 showed us the molecular structure and the photovoltaic performance of based solar cells [39-50].

Carboxylate polypyridyl ruthenium sensitizers are easily to be desorbed from the surface in the aqueous solution when the $\mathrm{pH}$ value is lower than 5 though they have a lot of advantages. While the phosphonate polypyridyl ruthenium sensitizers used phosphonate group to be anchored to the surface of the semiconductor, which is hardly desorpted from the semiconductor surface even at high $\mathrm{pH}$ value, however, phosphonate group is not in conjugation with the polypyridyl plane due to their non-plane structures, which is in disadvantage to the injection of electrons. Péchy et al. [49] developed the first phosphonate polypyridyl ruthenium dye (complex 1) that have the lifetime of excited state of 15 nanoseconds and the Langmuir adsorption coefficient of $8 \times 10^{6}$, which is 80 times larger than that of the N3 dye. The incident photon-current conversion efficiency of complex 1 achieves the maximum $70 \%$ at the wavelength of $510 \mathrm{~nm}$.
Grätzel et al. [48] developed the phosphonate polypyridyl ruthenium analogue of Z907 and gained the conversion efficiency of more than $8 \%$ for the solar cells that based.

Polynuclear complexes exhibiting an antenna effect have been employed in order to increase absorption coefficients. However, the antenna does not enhance the light response efficiently at longer wavelengths, where absorption coefficients and the IPCE of ruthenium charge-transfer sensitizers decrease strongly. Moreover, these bulky sensitizers require more space on the $\mathrm{TiO}_{2}$ surface and penetrate less easily in the small cavities of the nanocrystalline $\mathrm{TiO}_{2}$ than the mononuclear complexes. Hence, for polynuclear complexes, the increased absorption coefficients in solution do not necessarily lead to the enhanced light absorption on the $\mathrm{TiO}_{2}$ electrode due to the reduced surface concentration of the bulkier sensitizer molecules on the nanoporous $\mathrm{TiO}_{2}[51]$.

Organic dye is easy to be designed and various in style with molar extinction coefficient and low cost. In recent years, the development of DSC based on organic dye is very rapid and the conversion efficiency of the solar cells that based is comparable to that based on polypyridyl ruthenium dye. Generally, organic dye has the general structure of "Donor (D)- $\pi$ conjugation bridge-acceptor (A)." With the electron withdrawing and donating effects of acceptor and the donor moieties, the absorption response of the visible light are red-shifted, which improves the light harvesting and short circuit photocurrent of the solar cells. Figure 5 showed us the structure of several organic dyes and the conversion efficiency of based DSC [52-62]. Huang et al. [62] developed hemicyanine dyes BTS and IDS and get the efficiency $5.1 \%$ and $4.8 \%$ for solar cells that based. Yang et al. [59] reported the organic dye containing thienothiophene and thiophene segments and achieved high solar energy-toelectricity conversion efficiency of $6.23 \%$ for D-ST (structure shown in Figure 5) sensitized solar cells. Yanagida group [57] and Arakawa group [58] reported polyene dye or socalled phenyl-conjugated oligoene dye and gained the efficiency of $6.6 \%$ and $6.8 \%$. Hara et al. [53-56] developed a series of coumarin derivatives and received the efficiency of $7.7 \%$, which is comparable with that for N719. Uchida group [60] used indoline dye D149 as sensitizer and gained $8.0 \%$ conversion efficiency for solar cells without antireflection layer. Grätzel group [61] reported the $9.03 \%$ conversion efficiency for solar cells with D149 as sensitizer after optimizing nanocrystalline $\mathrm{TiO}_{2}$ films. This showed the new results for organic dye sensitized solar cells.

Sensitization with one single dye was restricted for its absorption spectrum is hardly matched with the solar emission spectrum. Cosensitization of several dyes with different spectral response instead of one single dye was used for wide-band-gap semiconductor. Zhang et al. [63, 64] used a series of squaraine dye as cosensitizer of ruthenium polypyridyl complexes and improved $13 \%$ efficiency for dyesensitized solar cells than those sensitized with simple ruthenium polypyridyl complexes. By cosensitization of squaraine dye and polypyridyl ruthenium dye in a proper ratio, the spectral response scope was widened the photovoltaic performance of based solar cells was improved. 


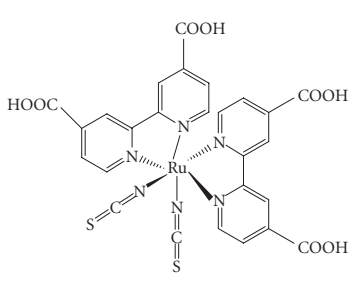

N3

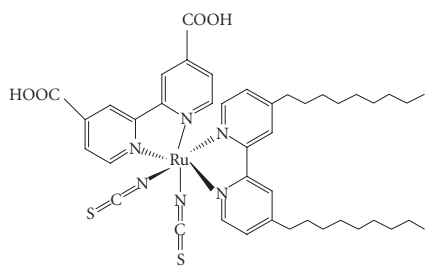

Z-907

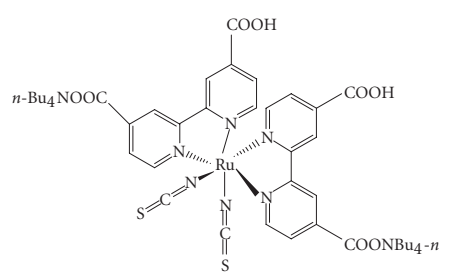

N719

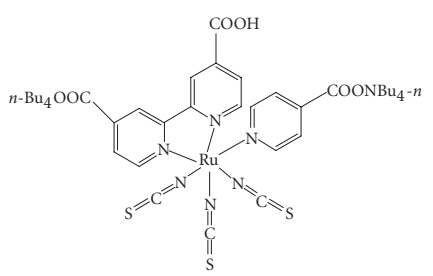

Black dye

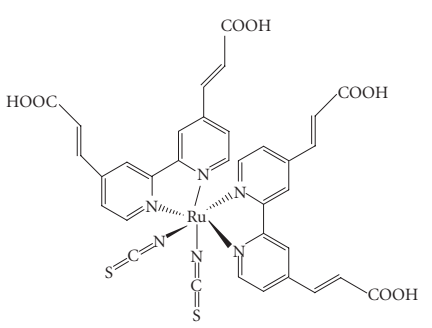

К8

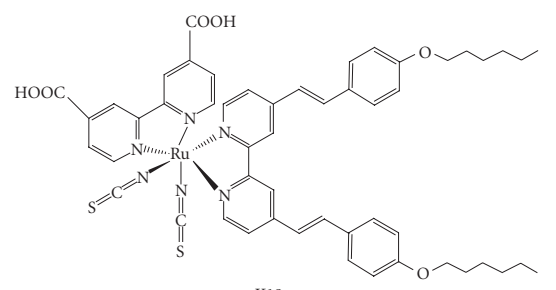

K19

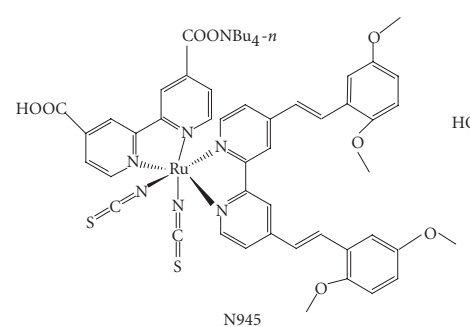

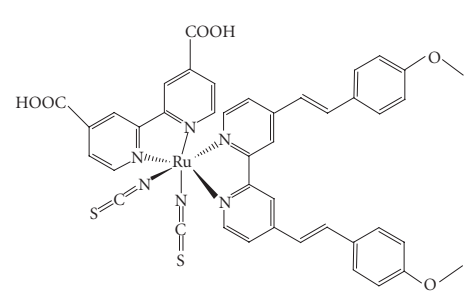

K73
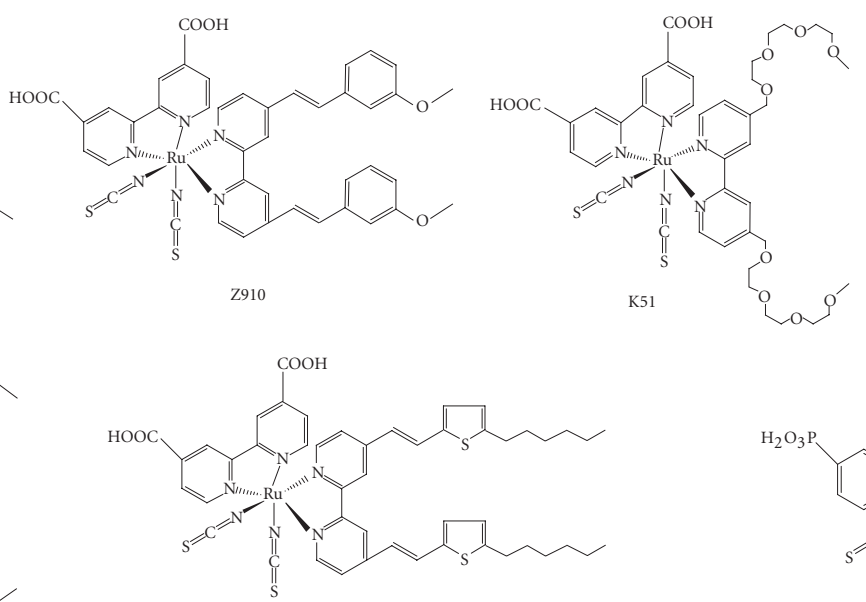

HRS-1
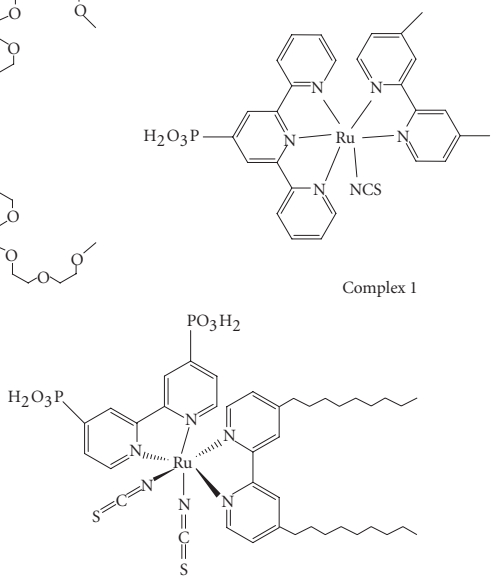

Z955

FIgURE 4: Molecular structure of several ruthenium complexes dye.

\subsection{Electrolyte}

The electrolyte is one of key components for dye-sensitized solar cells and its properties have much effect on the conversion efficiency and stability of the solar cells. The electrolyte used in DSC is divided into three types: liquid electrolyte, quasi-solid, state electrolyte, and solid electrolyte. Liquid electrolyte could be divided into organic solvent electrolyte and ionic liquid electrolyte according to the solvent used.

Organic solvent electrolytes were widely used and investigated in dye-sensitized solar cells for their low viscosity, fast ion diffusion, high efficiency, easy to be designed, and high pervasion into nanocrystalline film electrode [2-7, 65-68]. The composition of the electrolytes includes organic solvent, redox couple, and additive.

Organic solvent used in organic liquid electrolyte include nitrile such as acetonitrile, valeronitrile, 3-methox- ypropionitrile, and esters such as ethylene carbonate (EC), propylene carbonate (PC), $\gamma$-butyrolactone.

The major redox couple contained $\mathrm{I}_{3}{ }^{-} / \mathrm{I}^{-}$couple. Expecting that redox couple, Wang et al. [69] used $\mathrm{Br}^{-} / \mathrm{Br}_{2}$ as redox couple in eosin sensitized solar cells. $\mathrm{SCN}^{-} /(\mathrm{SCN})_{2}$ couple, $\mathrm{SeCN}^{-} /(\mathrm{SeCN})_{2}$ couple were also shown in the literature [70, 71]. Sapp [72] reported the substituted bipyridyl cobalt(III/II) couple as redox couple in DSC. However, the performance of these couples can hardly match that of $\mathrm{I}_{3}{ }^{-} / \mathrm{I}^{-}$ couple.

Alkyl imidazolium cation and lithium cation were usually used as the counterions of $\mathrm{I}_{3}{ }^{-} / \mathrm{I}^{-}$couple in DSC. Alkyl imidazolium cation may be adsorbed on the surface of semiconductor film to form the Helmholz layer, which restricted the contact of triiodide and semiconductor films, for the recombination between triiodide and electron in the conduction band of semiconductor. As the result, the fill factor, and conversion efficiency of the solar cells were improved. On the 
TABLE 1: Absorption spectra and photoelectric performance of different polybipyridyl ruthenium(II) complexes.

\begin{tabular}{|c|c|c|c|c|c|c|}
\hline Dye & $\begin{array}{c}A b s / \mathrm{nm} \\
\left(\varepsilon / 10^{3} \mathrm{~m}^{2} \mathrm{~mol}^{-1}\right)\end{array}$ & $\operatorname{IPCE}^{(\mathrm{a})}$ & $J_{\mathrm{sc}} / \mathrm{mA} \cdot \mathrm{cm}^{-2}$ & $V_{\mathrm{oc}} / \mathrm{mV}$ & FF & $\eta / \%$ \\
\hline N3 & $534(1.42)$ & $83 \%$ & 18.2 & 720 & 0.73 & $10[2]$ \\
\hline N719 & $532(1.4)$ & $85 \%$ & 17.73 & 846 & 0.75 & $11.18[8]$ \\
\hline Black Dye & $605(0.75)$ & $80 \%$ & 20.53 & 720 & 0.704 & $10.4[3]$ \\
\hline Black Dye & - & $80 \%$ & 20.9 & 736 & 0.722 & $11.1[6,7]$ \\
\hline Z907 & $526(1.22)$ & $72 \%$ & 13.6 & 721 & 0.692 & $6.8[39,42]$ \\
\hline Z907 & $526(1.22)$ & $72 \%$ & 14.6 & 722 & 0.693 & $7.3[39]$ \\
\hline K8 & $555(1.80)$ & $77 \%$ & 18 & 640 & 0.75 & $8.64[40]$ \\
\hline K19 & $543(1.82)$ & $70 \%$ & 14.61 & 711 & 0.671 & $7.0[41]$ \\
\hline N945 & $550(1.89)$ & $80 \%$ & 16.5 & 790 & 0.72 & $9.6[43]$ \\
\hline Z910 & $543(1.70)$ & $80 \%$ & 17.2 & 777 & 0.764 & $10.2[44]$ \\
\hline K73 & $545(1.80)$ & $80 \%$ & 17.22 & 748 & 0.694 & $9.0[45]$ \\
\hline K51 & $530(1.23)$ & $70 \%$ & 15.40 & 738 & 0.685 & $7.8[46]$ \\
\hline HRS-1 & $542(1.87)$ & $80 \%$ & 20 & 680 & 0.69 & 9.5 [47] \\
\hline Z955 & $519(0.83)$ & $80 \%$ & 16.37 & 707 & 0.693 & $8.0[48]$ \\
\hline
\end{tabular}

(a) Platform region. IPCE, Incident photon-current conversion efficiency.

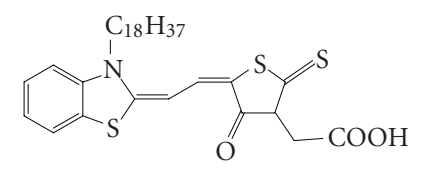

Merocyanine dye MC[18, 1$], \eta=4.5 \%$

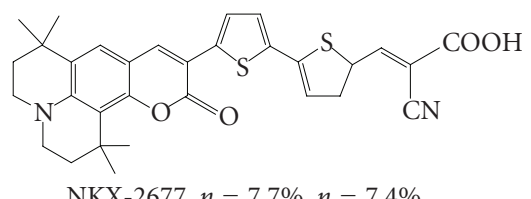

NKX-2677, $\eta=7.7 \%, \eta=7.4 \%$

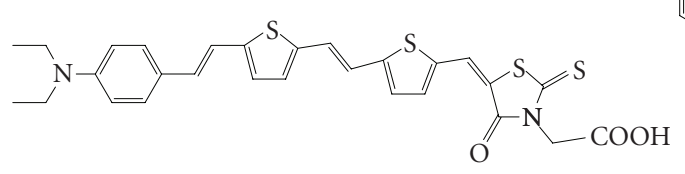

D-SS, $\eta=6.23 \%$
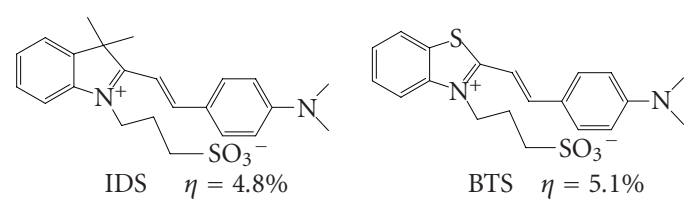

Hemicyanine dye
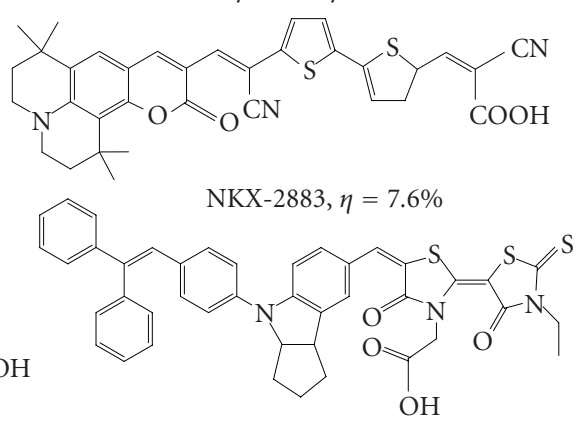

Indoline dye D149, $\eta=8 \%, 9.03 \%$
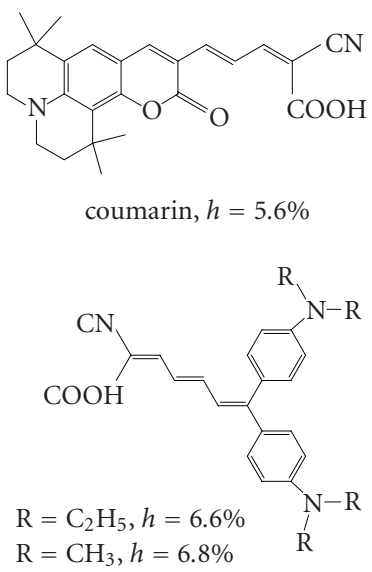

Phenyle-conjugated

Oligoene dye, polyene dye

FIGURE 5: Photoelectric conversion efficiency of DSC based on several organic dyes with high extinction coefficient and their molecular structure.

other hand, the high solubility of alkyl imidazolium cation in organic solvent and the high activity of iodide increased the light harvesting efficiency and photocurrent as well as the stability of the sensitizer.

The commonly used additive used in the electrolytes for dye-sensitized solar cells contained 4-tert-butylpyridine (TBP) and N-methylbenzimidazole (NMBI). The addition of these additives could suppress the dark current and improve the photoelectric conversion efficiency. TBP could reduce the recombination of electrons in the conduction band of the semiconductor and the electron acceptor in the electrolyte through the coordination between $\mathrm{N}$ atom and the Ti ion in incomplete coordination state on the surface of $\mathrm{TiO}_{2}$ film. Then, the photovoltage fill factor and the conversion efficiency increased dramatically.

The efficiency record of DSC was obtained on the solar cells based on organic solvent electrolyte, especially the highly volatile organic solvent electrolyte due to the efficient 


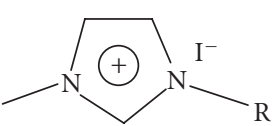

1-methyl-3-alkylimidazolium iodide

$\mathrm{R}=\mathrm{C}_{3}-\mathrm{C}_{9}$ alkyl.

$\eta_{a} / \mathrm{mPa} \cdot \mathrm{s}: \mathrm{C}_{3}, 865, \mathrm{C}_{4}, 963, \mathrm{C}_{5}, 1362$

$\mathrm{C}_{6}, 1439, \mathrm{C}_{7}, 1792, \mathrm{C}_{8}, 1976, \mathrm{C}_{9}, 2099$

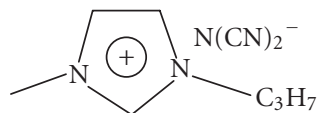

MPIDCN

$\eta_{a} / \mathrm{mPa} \cdot \mathrm{s}: 18$

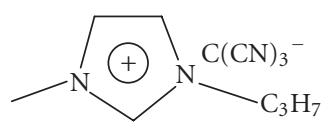

$\mathrm{MPIC}(\mathrm{CN})_{3}$

$\eta_{a} / \mathrm{mPa} \cdot \mathrm{s}: 18$
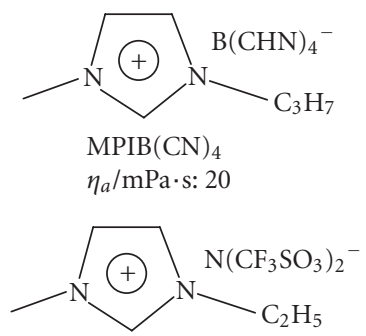

EMITFSI

$\eta_{a} / \mathrm{mPa} \cdot \mathrm{s}: 39$

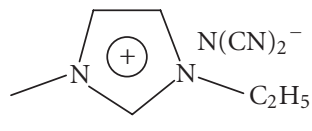

EMIDCN

$\eta_{a} / \mathrm{mPa} \cdot \mathrm{s}: 21$

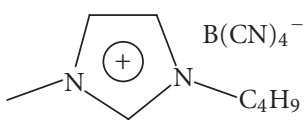

$\mathrm{BMIB}(\mathrm{CN})_{4}$

$\eta_{a} / \mathrm{mPa} \cdot \mathrm{s}: 20$

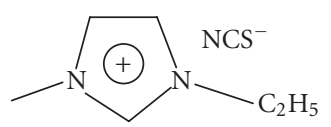

EMINCS

$\eta_{a} / \mathrm{mPa} \cdot \mathrm{s}: 21$

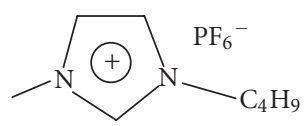

$\mathrm{BMIPF}_{6}$

$\eta_{a} / \mathrm{mPa} \cdot \mathrm{s}: 352$

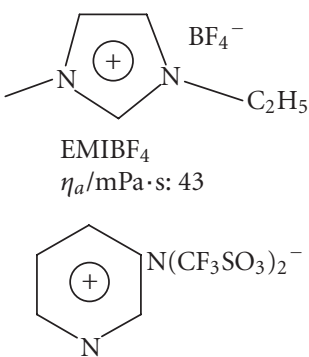

BPITFSI

$\eta_{a} / \mathrm{mPa} \cdot \mathrm{s}: 72$

FIGURE 6: Structure and the viscosity of several ionic liquids.

infiltration of organic electrolyte in nanocrystalline films. However, the solar cells based on organic electrolyte have the disadvantages such as less long-term stability, difficulty in robust sealing and leakage of electrolyte due to the volatility of organic solvent.

Ionic liquid electrolytes were developed in recent year in view of the disadvantage of organic solvent electrolyte. Compared with normal organic solvent electrolyte, ionic liquid have a lot of advantage, such as good chemical and thermal stability, negligible vapor pressure, nonflammability, high ionic conductivity and high solubility for organic or inorganic materials, and a wide electrochemical window, which has been intensively pursued as alternative electrolytes for DSC and other electrochemical devices. In recent years, ionic liquid electrolyte was developed rapidly. Kubo et al. [73] investigated the physical and physiochemical properties of 1-alkyl-3-methylimidazolium iodides (alkyl chain: C3-C9). They found that the viscosity of the molten salts increases with increasing alkyl chain length because of van der Waals forces. The conductivity of the molten salts decreases with increasing viscosity since the diffusion of ions in a liquid depends on its viscosity. The electrolyte with 1-hexyl-3-methylimidazolium iodide gave the highest photoelectric conversion efficiency. Among these ionic liquids, alkyl imidazolium-based ionic liquids are both iodide sources and solvents of electrolytes in solar cells. The counterions in the alkyl imidazolium-based ionic liquid included $\mathrm{I}^{-}, \mathrm{N}(\mathrm{CN})_{2}{ }^{-}, \mathrm{B}(\mathrm{CN})_{4}{ }^{-},\left(\mathrm{CF}_{3} \mathrm{COO}\right)_{2} \mathrm{~N}^{-}, \mathrm{BF}_{4}{ }^{-}, \mathrm{PF}_{6}{ }^{-}, \mathrm{NCS}^{-}$, and so forth 1-Alkyl-3-methylimidazolium iodides are viscous liquids, whose viscosity is much higher than that of organic-solvent-based liquid electrolyte. Then the transport $\mathrm{I}_{3}{ }^{-}$in the electrolyte is very slow and the mass transfer process occupies the leading position. To improve the mobility of redox couple in the electrolyte and the photovoltaic performance, various ionic liquid with low viscosity were developed. Grätzel et al. reported the solar cells based on low-viscosity ionic liquid and MPII mixture. Figure 6 and Table 2 summarize the structure and viscosity of some ionic liquid and the photovoltaic performance of DSC based on ionic liquid electrolyte of different composition [73-83].

Besides alkyl imidazolium cation, alkyl pyridinium salt and trialkylmethylsulfonium-salt-based ionic liquid were developed for electrolytes. Paulsson et al. [74] obtained 3.7\% photoelectric conversion efficiency for solar cells based on $\left(\mathrm{Bu}_{2} \mathrm{Me}\right) \mathrm{SI}$ ionic liquid containing $1 \%$ iodine. Watanabe [81] reported $2 \%$ conversion efficiency in alkyl pryidiniumcation-based ionic liquid. Wang [75] achieved 7.5\% efficiency in solvent-free EMISeCN-based ionic liquid containing $(\mathrm{SeCN})_{3}^{-} / \mathrm{SeCN}^{-}$electrolyte, which is comparable with $\mathrm{I}_{3}{ }^{-} / \mathrm{I}^{-}$couple. However, the rareness of selenium and high costs has limited its application in DSC. Matsui [83] reported the application of ionic liquid electrolyte in large-area solar cells and gained $2.17 \%$ conversion efficiency $2.7 \%$.

The evaporation of the liquid electrolyte often caused some practical limitations of sealing and long-term operation. Recently some attempts were made to improve the long-term stability by using a p-type semiconductor $[89,90]$ or hole transporting organic materials [91] to replace a liquid electrolyte. However, their conversion efficiencies are not comparable with those of the liquid solar cells. Thus, it can be seen that quasi-solid-state ionic liquid electrolytes might be a better choice to increase stability. Owing to their unique physicochemical properties such as high thermal stability, negligible vapor pressure, relatively high ionic conductivity, and good stability, Ionic liquids were widely used in dyesensitized solar cells. In general, quasi-solid-state ionic liquid electrolyte consists of $\mathrm{I}_{3}{ }^{-} / \mathrm{I}^{-}$couple such as 1-methyl-3propylimidazolium iodine (MPII) and framework materials. In quasi-solid electrolytes, framework materials play an important role in offering a liquid channel for the $\mathrm{I}_{3}{ }^{-} / \mathrm{I}^{-}$diffusion. Some polymers, [83-86, 92-97] low-molecular-weight gelator $[73,80]$, and silica nanoparticles [77, 87] have been 
TABLE 2: Efficiency of DSC based on ionic liquid electrolyte system with different composition.

\begin{tabular}{|c|c|c|}
\hline Composion of electrolyte & Dye & $\eta / \%$ \\
\hline \multirow{2}{*}{$\mathrm{I}_{2}$, LiI, and NMBI in PMII and EMIDCN $(13: 7, \mathrm{v} / \mathrm{v})$} & Z907 & $6.6[76]$ \\
\hline & N719 & $5.0[76]$ \\
\hline HMII, $\mathrm{I}_{2}$ et al. & N719 & $5.0[73]$ \\
\hline $\mathrm{I}_{2}$ and $\mathrm{NMBI}$ in MPII & Z907 & $6.0[77]$ \\
\hline $\mathrm{I}_{2}, \mathrm{GuSCN}, \mathrm{TBP}$ in PMII and EMINCS $(13: 7, \mathrm{v} / \mathrm{v})$ & Z907 & 7.0 and $6.4^{*}[78]$ \\
\hline $\mathrm{I}_{2}, \mathrm{NMBI}$, and GuSCN in MPII and $\operatorname{EMIB}(\mathrm{CN})_{4}(13: 7, \mathrm{v} / \mathrm{v})$ & Z907 & 7.0 and $6.4^{*}[79]$ \\
\hline \multirow{2}{*}{$\mathrm{I}_{2}, \mathrm{GuSCN}$, and NMBI in PMII and EMINCS $(13: 7, \mathrm{v} / \mathrm{v})$} & Z955 & $5.5[48]$ \\
\hline & K19, DPA & $6.3[80]$ \\
\hline MPII, LiI, $\mathrm{I}_{2}$ TBP in EMIDCA & $\mathrm{N} 3$ & $5.5[81]$ \\
\hline MPII, LiI, $\mathrm{I}_{2}$, TBP in EMITFSI & N3 & $4.5[81]$ \\
\hline $\mathrm{I}_{2}$ and NMBI in PMII and functional PMII derivative ionic liquids $(13: 7, \mathrm{v} / \mathrm{v})$ & K19 PPA & $5.4 \sim 5.9[82]$ \\
\hline EMII, $\mathrm{I}_{2}, \mathrm{LiI}, \mathrm{TBP}$ in EMITFSA & N3 & $\begin{array}{l}4.5\left(0.45 \mathrm{~cm}^{2}\right) \\
2.7\left(69 \mathrm{~cm}^{2}\right)[83]\end{array}$ \\
\hline$\left(\mathrm{Bu}_{2} \mathrm{Me}\right) \mathrm{SI}$ and $1 \% \mathrm{I}_{2}, \mathrm{TBP}$ & N719 & $3.7(0.1$ sun $)[74]$ \\
\hline MPII, LiI, $\mathrm{I}_{2}$ TBP in PTFSI & N3 & $2 \%[81]$ \\
\hline $\mathrm{GuSCN}, \mathrm{K}(\mathrm{SeCN})_{3}, \mathrm{NMBI}$ in EMISeCN & Z907, PPA & $7.5[75]$ \\
\hline
\end{tabular}

* With and without PPA as coadsorbent, PTFSI: 1-butylpyridinium bis-(trifluoromethane sulfonyl)imide.

TABLE 3: Photovoltaic performance of quasi-solid-state DSC with different gelators and ionic liquid electrolytes.

\begin{tabular}{|c|c|c|c|}
\hline Composition & Gelator & Dye & $\eta / \%$ \\
\hline HMII, $\mathrm{I}_{2}$ et al. & Low-molecular-weight gelator & N719 & $5.01[73]$ \\
\hline $\mathrm{I}_{2}, \mathrm{MPII}, \mathrm{NMBI}$ & PVDF-HFP & Z907 & $5.3[84]$ \\
\hline $\mathrm{I}_{2}$ and $\mathrm{NMBI}$ in MPII & Silica Nanoparticles & Z907 & $6.1[77]$ \\
\hline $\mathrm{I}_{2}, \mathrm{GuSCN}, \mathrm{NMBI}$ in PMII/EMINCS $(13: 7, \mathrm{v} / \mathrm{v})$ & Low-molecular-weight gelator & K-19 DPA & $6.3[80]$ \\
\hline EMImI, $\mathrm{I}_{2}$, LiI, TBP in EMITFSA & PVDF-HFP & N3 & $\begin{array}{l}3.8\left(0.45 \mathrm{~cm}^{2}\right) \\
2.4\left(69 \mathrm{~cm}^{2}\right)[83]\end{array}$ \\
\hline TMS-PMII/ $\mathrm{I}_{2}$ in $10: 1$ ratio & Self-gelation & N3 & $3.2[85]$ \\
\hline $\mathrm{I}_{2}, \mathrm{LiI}, \mathrm{TBP}$ in MPII & Agarose & N719 & $2.93[86]$ \\
\hline $\mathrm{I}_{2}$, LiI, TBP, DMPII in EMIDCA & Agarose & N719 & $3.89[86]$ \\
\hline EMII, LiI, $\mathrm{I}_{2}$, and TBP in EMITFSI & Nanoparticles & N3 & $4.57 \sim 5.00[87]$ \\
\hline
\end{tabular}

used as framework materials to solidify ionic liquid-based electrolyte in DSC. Table 3 summarizes the photovoltaic performance of DSC based on different gelators and ionic liquid electrolytes.

\section{SUMMARY}

In the past ten years, different efficiency records were announced for dye-sensitized solar cells with different active area in the laboratories and corporations in the world. More than $11 \%$ efficiency have achieved by EPFL and Sharp Corporation in small-area DSC. The conversion efficiency record of $8.12 \%, 10.1 \%, 10.4 \%, 9.9 \%$ was announced by ECN, EPFL, Sharp Corporation, Arakawa group for strip solar cells with aperture area of $1 \sim 5 \mathrm{~cm}^{2}$, which is comparable to that for small-area solar cells. Table 4 showed us the conversion efficiency record reported by the main research team of dye-sensitized solar cells or DSC modules. It can be seen that the module efficiency is still low for practical application. Since 1993, industrial researchers have led the way with teams from Germany, Australia, and Switzerland. Based on licenses to the core patents held by EPFL, these teams built strong bases for product development. A $200 \mathrm{~m}^{2}$ DSC showcase in roof has been constructed by the STI Company in 
TABLE 4: Photoelectric conversion efficiency of DSC in the world [5-17, 88]. EPFL: Laboratory for Photonic and Interfaces, Swiss. NREL: National Renewable Energy Laboratory, USA. ECN: Energy Research Centre of the Netherlands. STI: Sustainable Technology International, Australia. SHARP: Sharp Corporation. INAP: Institute of Photovoltaic, Germany. TUS: Tokyo University of Science. FMRC: Freiburg Materials Research Centre. IPP: Institute of Plasma Physics, Chinese Academy of Sciences. Data reported above were measured using solar simulator indoor $\left(\mathrm{AM} 1.5,100 \mathrm{~mW} / \mathrm{cm}^{2}\right)$ if there is no further statement.

\begin{tabular}{|c|c|c|c|c|c|}
\hline & $<0.5 \mathrm{~cm}^{2}$ & $1 \sim 5 \mathrm{~cm}^{2}$ & $100 \mathrm{~cm}^{2}$ & $300 \mathrm{~cm}^{2}$ & $400 \mathrm{~cm}^{2}$ \\
\hline EPFL & $\begin{array}{l}10.58 \%(2003) \\
11.04 \%(2004) \\
11.18 \%(2006)\end{array}$ & $\begin{array}{l}10.1 \%(2006) \\
\left(1.31 \mathrm{~cm}^{2}\right)\end{array}$ & - & - & - \\
\hline NREL & $9 \%(2000)$ & - & - & - & - \\
\hline $\mathrm{ECN}$ & - & $8.2 \%(2001)$ & $\begin{array}{l}\text { Highest:5.9\% (2003) } \\
\text { Lowest:4.5\% }\end{array}$ & - & $\begin{array}{l}4.7 \%(2003) \\
\text { Outdoor }\end{array}$ \\
\hline STI & - & - & - & $<3 \%$ & - \\
\hline SHARP & $\begin{array}{l}10.8 \%(2005) \\
\left(0.2227 \mathrm{~cm}^{-2}\right) \\
11.1 \% \\
\left(0.219 \mathrm{~cm}^{2}\right)\end{array}$ & $\begin{array}{l}10.4 \%(2005) \\
\left(1.004 \mathrm{~cm}^{2}\right) \\
8.0 \%(2006) \\
\left(5 \mathrm{~cm}^{2}\right)\end{array}$ & $\begin{array}{l}6.3 \%\left(26.5 \mathrm{~cm}^{2}, \text { confirmed }\right) \\
6.3 \%\left(101 \mathrm{~cm}^{2}\right)\end{array}$ & - & - \\
\hline INAP & - & - & $4.7 \%(1998)\left(141.4 \mathrm{~cm}^{2}\right.$, confirmed $)$ & - & $6.8 \%(2000)$ \\
\hline TUS & $10.3 \%(2006)$ & $9.9 \%(2006)$ & $8.4 \%(2006)\left(67.5 \mathrm{~cm}^{2}\right)$ & - & - \\
\hline FMRC & - & - & - & $3.5 \%(2006)$ & - \\
\hline IPP & $8.95 \%(2002)$ & $7.4 \%(2003)$ & - & $\begin{array}{l}5.9 \%(1 \text { sun })(2003) \\
7.3 \%(0.5 \text { sun })\end{array}$ & $\begin{array}{l}5.7 \%(2003) \\
(0.95 \text { sun, outdoor })\end{array}$ \\
\hline
\end{tabular}

2003. Sharp Corporation and Arakawa group reported $6.3 \%$ (efficient area: $26.5 \mathrm{~cm}^{2}$, confirmed, $6.3 \%$ for $101 \mathrm{~cm}^{2}$ ) and $8.4 \%\left(100 \mathrm{~cm}^{2}\right)$ conversion efficiency for DSC modules. Our group have prepared the DSC modules with efficiency more than $6 \%$ in the size of $15 \mathrm{~cm} \times 20 \mathrm{~cm}$. Many corporations in Japan have focused on DSC research and have got good results in organic dye-sensitized solar cells and flexible solar cells. Gifu University (Japan) developed colorful plastic solar cells with the efficiency of $5.6 \%$ based on organic indoline dye and electrodeposited nanocrystalline $\mathrm{ZnO}$ film electrode. Toin University of Yokohama (Japan) has achieved more than $6 \%$ conversion efficiency on full flexible solar cells based on low-temperature $\mathrm{TiO}_{2}$ electrode preparation technology. Peccell Technologies (Japan) have succeeded in the development of full flexible substrate DSC with the size of $12 \mathrm{~cm} \times 12 \mathrm{~cm}$, voltage more than $4 \mathrm{~V}$, current $0.1 \mathrm{~A}$ and the efficiency of 4.3\% 5.2\%. Konarka Corporation and G24 in England are currently setting-up pilot production in their 20 MW factory facility.

Industrial research in China was under the financial support of the National Basic Research Program of China and CAS Innovation Program. After five years, $15 \mathrm{~cm} \times 20 \mathrm{~cm}$ DSC modules were prepared and assembled to $45 \mathrm{~cm} \times$ $80 \mathrm{~cm}$ DSC panel, and the efficiency of the DSC modules and panels is more than 5\%. In 2004, a $500 \mathrm{~W}$ DSC showcase was founded and generated electricity without obvious performance degradation until now [98]. The fundamental and industrial researches have been carried out since 1994. There are more than 30 groups engaged in the research of DSC. The research involved the dye sensitizers, nanocrystalline semiconductor film, electrolyte, counter electrode, substrate and theoretical research of interface transport, and so forth. In the near future, DSC panels that have outstanding architectural appeal are forecast to be in wide use in the commercial market. Within a few years, lower cost rigid and flexible products will become available. Later in the decade, electrophotochromic windows should be commercialized. During the next decade, the introduction of tandem water-splitting devices is possible.

\section{ACKNOWLEDGMENTS}

This project was financially supported by National Basic Research Program of China (Grant no. 2006CB202600) and the Anhui Province Key Technologies R \& D Programme (Grant no. $06012024 \mathrm{~A})$.

\section{REFERENCES}

[1] B. O’Regan and M. Grätzel, "A low-cost, high-efficiency solar cell based on dye-sensitized colloidal $\mathrm{TiO}_{2}$ films," Nature, vol. 353, no. 6346, pp. 737-740, 1991. 
[2] M. K. Nazeeruddin, A. Kay, I. Rodicio, et al., "Conversion of light to electricity by cis- $\mathrm{X}_{2}$ bis $\left(2,2^{\prime}\right.$-bipyridyl-4,4' dicarboxylate)ruthenium(II) charge-transfer sensitizers ( $\mathrm{X}=$ $\mathrm{Cl}^{-}, \mathrm{Br}^{-}, \mathrm{I}^{-}, \mathrm{CN}^{-}, \mathrm{SCN}^{-}$) on nanocrystalline $\mathrm{TiO}_{2}$ electrodes," Journal of the American Chemical Society, vol. 115, no. 14, pp. 6382-6390, 1993.

[3] M. K. Nazeeruddin, P. Péchy, T. Renouard, et al., "Engineering of efficient panchromatic sensitizers for nanocrystalline $\mathrm{TiO}_{2}$ based solar cells," Journal of the American Chemical Society, vol. 123, no. 8, pp. 1613-1624, 2001.

[4] M. Grätzel, "Photoelectrochemical cells," Nature, vol. 414, no. 6861, pp. 338-344, 2001.

[5] M. Grätzel, "Conversion of sunlight to electric power by nanocrystalline dye-sensitized solar cells," Journal of Photochemistry and Photobiology A, vol. 164, no. 1-3, pp. 3-14, 2004.

[6] L. Han, Y. Chiba, A. Islam, et al., "High efficiency of dyesensitized solar cells and module," in The 16th International Conference of Photochemical Conversion and Solar Storage, Uppsala, Sweden, July 2006, W4-P-11.

[7] Y. Chiba, A. Islam, Y. Watanabe, R. Komiya, N. Koide, and L. Han, "Dye-sensitized solar cells with conversion efficiency of 11.1\%," Japanese Journal of Applied Physics, vol. 45, no. 25, pp. L638-L640, 2006.

[8] M. K. Nazeeruddin, F. De Angelis, S. Fantacci, et al., "Combined experimental and DFT-TDDFT computational study of photoelectrochemical cell ruthenium sensitizers," Journal of the American Chemical Society, vol. 127, no. 48, pp. 1683516847, 2005.

[9] M. Späth, J. V. Roosmalen, P. Sommeling, et al., "Dye sensitised solar cells from laboratory scale to pre-pilot stage," in Proceddings of the 3rd World Conference on Photovoltaic Energy Conversion (WCPEC '03), vol. 1, pp. 196-199, Osaka, Japan, May 2003.

[10] J. M. Kroon, N. J. Bakker, H. J. P. Smit, et al., "Nanocrystalline dye-sensitized solar cells having maximum performance," Progress in Photovoltaics: Research and Applications, vol. 15, no. 1, pp. 1-18, 2007.

[11] H. Arakawa, T. Yamaguchi, A. Takeuchi, et al., "Preparation of $10 \mathrm{~cm}$-by-10 cm size black dye sensitized solar cells with $8.4 \%$ efficiency," in The 16th International Conference of Photochemical Conversion and Solar Storage, Uppsala, Sweden, July 2006, W4-P-10.

[12] M. A. Green, K. Emery, D. L. King, S. Igari, and W. Warta, "Solar cell efficiency tables (version 20)," Progress in Photovoltaics: Research and Applications, vol. 10, no. 5, pp. 355-360, 2002.

[13] Y. Chiba, A. Islam, K. Kakutani, R. Komiya, N. Koide, and L. Han, "High efficiency dye sensitized solar cells," in Proceedings of the 15th International Photovoltaic Science \& Engineering Conference (PVSEC '05), pp. 665-666, Shanghai, China, October 2005.

[14] S.-Y. Dai, J. Weng, Y. Sui, et al., "Dye-sensitized solar cells, from cell to module," Solar Energy Society World Congress, vol. 84, no. 1-4, pp. 125-133, 2004.

[15] S.-Y. Dai, K.-J. Wang, J. Weng, et al., "Design of DSC panel with efficiency more than 6\%," Solar Energy Materials and Solar Cells, vol. 85, no. 3, pp. 447-455, 2005.

[16] T. Yoshida, T. Oekermann, L. M. Peter, et al., "Electrodeposition of nano-structured porous crystalline $\mathrm{ZnO} /$ Dye hybrid thin films for plastic solar cells," in The 16th International Conference of Photochemical Conversion and Solar Storage, Uppsala, Sweden, July 2006, W4-O-2.

[17] T. Miyasaka, Y. Kijitori, and M. Ikegami, "Fabrication of full-plastic dye-sensitized sola cell modules based on lowtemperature coating techniques," in The 16th International
Conference of Photochemical Conversion and Solar Storage, Uppsala, Sweden, July 2006, W4-O-7.

[18] L. Hu, S.-Y. Dai, J. Weng, et al., "Microstructure design of nanoporous $\mathrm{TiO}_{2}$ photoelectrodes for dye-sensitized solar cell modules," Journal of Physical Chemistry B, vol. 111, no. 2, pp. 358-362, 2007.

[19] J.-H. Yum, S.-S. Kim, D.-Y. Kim, and Y.-E. Sung, "Electrophoretically deposited $\mathrm{TiO}_{2}$ photo-electrodes for use in flexible dye-sensitized solar cells," Journal of Photochemistry and Photobiology A, vol. 173, no. 1, pp. 1-6, 2005.

[20] F. Pichot, J. R. Pitts, and B. A. Gregg, "Low-temperature sintering of $\mathrm{TiO}_{2}$ colloids: application to flexible dye-sensitized solar cells," Langmuir, vol. 16, no. 13, pp. 5626-5630, 2000.

[21] C. Longo, A. F. Nogueira, M.-A. de Paoli, and H. Cachet, "Solid-state and flexible dye-sensitized $\mathrm{TiO}_{2}$ solar cells: a study by electrochemical impedance spectroscopy," Journal of Physical Chemistry B, vol. 106, no. 23, pp. 5925-5930, 2002.

[22] H. Lindström, A. Holmberg, E. Magnusson, S.-E. Lindquist, L. Malmqvist, and A. Hagfeldt, "A new method for manufacturing nanostructured electrodes on plastic substrates," Nano Letters, vol. 1, no. 2, pp. 97-100, 2001.

[23] H. Lindström, A. Holmberg, E. Magnusson, L. Malmqvist, and A. Hagfeldt, "A new method to make dye-sensitized nanocrystalline solar cells at room temperature," Journal of Photochemistry and Photobiology A, vol. 145, no. 1-2, pp. 107-112, 2001.

[24] T. Miyasaka, Y. Kijitori, T. N. Murakami, M. Kimura, and S. Uegusa, "Efficient nonsintering type dye-sensitized photocells based on electrophoretically deposited $\mathrm{TiO}_{2}$ layers," Chemistry Letters, vol. 31, no. 12, pp. 1250-1251, 2002.

[25] T. Miyasaka and Y. Kijitori, "Low-temperature fabrication of dye-sensitized plastic electrodes by electrophoretic preparation of mesoporous $\mathrm{TiO}_{2}$ layers," Journal of the Electrochemical Society, vol. 151, no. 11, pp. A1767-A1773, 2004.

[26] M. Dürr, A. Schmid, M. Obermaier, S. Rosselli, A. Yasuda, and G. Nelles, "Low-temperature fabrication of dye-sensitized solar cells by transfer of composite porous layers," Nature Materials, vol. 4, no. 8, pp. 607-611, 2005.

[27] T. Miyasaka and Y. Kijitori, "High efficient plastic dyesensitized solar cell based on the low-temperature TiO2 coating method," in The 16th International Conference of Photochemical Conversion and Solar Storage, Uppsala, Sweden, July 2006, W4-P-15.

[28] S. Ito, N.-L. C. Ha, G. Rothenberger, et al., "High-efficiency (7.2\%) flexible dye-sensitized solar cells with Ti-metal substrate for nanocrystalline- $\mathrm{TiO}_{2}$ photoanode," Chemical Communications, no. 38, pp. 4004-4006, 2006.

[29] S. Lee, J. Y. Kim, K. S. Hong, H. S. Jung, J.-K. Lee, and H. Shin, "Enhancement of the photoelectric performance of dyesensitized solar cells by using a $\mathrm{CaCO}_{3}$-coated $\mathrm{TiO}_{2}$ nanoparticle film as an electrode," Solar Energy Materials and Solar Cells, vol. 90, no. 15, pp. 2405-2412, 2006.

[30] H. S. Jung, J.-K. Lee, M. Nastasi, et al., "Preparation of nanoporous $\mathrm{MgO}$-coated $\mathrm{TiO}_{2}$ nanoparticles and their application to the electrode of dye-sensitized solar cells," Langmuir, vol. 21, no. 23, pp. 10332-10335, 2005.

[31] J.-H. Yum, S. Nakade, D.-Y. Kim, and S. Yanagida, "Improved performance in dye-sensitized solar cells employing $\mathrm{TiO}_{2}$ photoelectrodes coated with metal hydroxides," Journal of Physical Chemistry B, vol. 110, no. 7, pp. 3215-3219, 2006.

[32] D. B. Menzies, Q. Dai, Y.-B. Cheng, G. P. Simon, and L. Spiccia, "One-step microwave calcination of $\mathrm{ZrO}_{2}$-coated $\mathrm{TiO}_{2}$ electrodes for use in dye-sensitized solar cells," Comptes Rendus Chimie, vol. 9, no. 5-6, pp. 713-716, 2006. 
[33] E. Palomares, J. N. Clifford, S. A. Haque, T. Lutz, and J. R. Durrant, "Control of charge recombination dynamics in dye sensitized solar cells by the use of conformally deposited metal oxide blocking layers," Journal of the American Chemical Society, vol. 125, no. 2, pp. 475-482, 2003.

[34] G. R. R. A. Kumara, K. Tennakone, V. P. S. Perera, A. Konno, S. Kaneko, and M. Okuya, "Suppression of recombinations in a dye-sensitized photoelectrochemical cell made from a film of tin IV oxide crystallites coated with a thin layer of aluminium oxide," Journal of Physics D, vol. 34, no. 6, pp. 868-873, 2001.

[35] K. Tennakone, G. R. R. A. Kumara, I. R. M. Kottegoda, and V. P. S. Perera, "An efficient dye-sensitized photoelectrochemical solar cell made from oxides of tin and zinc," Chemical Communications, no. 1, pp. 15-16, 1999.

[36] A. Kay and M. Grätzel, "Dye-sensitized core-shell nanocrystals: improved efficiency of mesoporous tin oxide electrodes coated with a thin layer of an insulating oxide," Chemistry of Materials, vol. 14, no. 7, pp. 2930-2935, 2002.

[37] F.-T. Kong and S.-Y. Dai, "Dye-sensitized solar cells," Progress in Chemistry, vol. 18, no. 11, pp. 1409-1424, 2006.

[38] A. Hagfeldt and M. Grätzel, "Molecular photovoltaics," Accounts of Chemical Research, vol. 33, no. 5, pp. 269-277, 2000.

[39] P. Wang, S. M. Zakeeruddin, R. Humphry-Baker, J. E. Moser, and M. Grätzel, "Molecular-scale interface engineering of $\mathrm{TiO}_{2}$ nanocrystals: improving the efficiency and stability of dye-sensitized solar cells," Advanced Materials, vol. 15, no. 24, pp. 2101-2104, 2003.

[40] C. Klein, M. K. Nazeeruddin, P. Liska, et al., "Engineering of a novel ruthenium sensitizer and its application in dyesensitized solar cells for conversion of sunlight into electricity," Inorganic Chemistry, vol. 44, no. 2, pp. 178-180, 2005.

[41] P. Wang, C. Klein, R. Humphry-Baker, S. M. Zakeeruddin, and M. Grätzel, "A high molar extinction coefficient sensitizer for stable dye-sensitized solar cells," Journal of the American Chemical Society, vol. 127, no. 3, pp. 808-809, 2005.

[42] P. Wang, S. M. Zakeeruddin, J. E. Moser, M. K. Nazeeruddin, T. Sekiguchi, and M. Grätzel, "A stable quasi-solid-state dyesensitized solar cell with an amphiphilic ruthenium sensitizer and polymer gel electrolyte," Nature Materials, vol. 2, no. 6, pp. 402-407, 2003.

[43] M. K. Nazeeruddin, Q. Wang, L. Cevey, et al., "DFT-INDO/S modeling of new high molar extinction coefficient chargetransfer sensitizers for solar cell applications," Inorganic Chemistry, vol. 45, no. 2, pp. 787-797, 2006.

[44] P. Wang, S. M. Zakeeruddin, J. E. Moser, et al., "Stable new sensitizer with improved light harvesting for nanocrystalline dye-sensitized solar cells," Advanced Materials, vol. 16, no. 20, pp. 1806-1811, 2004.

[45] D. Kuang, S. Ito, B. Wenger, et al., "High molar extinction coefficient heteroleptic ruthenium complexes for thin film dyesensitized solar cells," Journal of the American Chemical Society, vol. 128, no. 12, pp. 4146-4154, 2006.

[46] D. Kuang, C. Klein, H. J. Snaith, et al., "Ion coordinating sensitizer for high efficiency mesoscopic dye-sensitized solar cells: influence of lithium ions on the photovoltaic performance of liquid and solid-state cells," Nano Letters, vol. 6, no. 4, pp. 769$773,2006$.

[47] K.-J. Jiang, N. Masaki, J.-B. Xia, S. Noda, and S. Yanagida, "A novel ruthenium sensitizer with a hydrophobic 2-thiophen2-yl-vinyl- conjugated bipyridyl ligand for effective dye sensitized $\mathrm{TiO}_{2}$ solar cells," Chemical Communications, no. 23, pp. 2460-2462, 2006.

[48] P. Wang, C. Klein, J.-E. Moser, et al., "Amphiphilic ruthenium sensitizer with $4,4^{\prime}$-diphosphonic acid-2,2' -bipyridine as anchoring ligand for nanocrystalline dye sensitized solar cells," Journal of Physical Chemistry B, vol. 108, no. 45, pp. 17553-17559, 2004.

[49] P. Péchy, F. P. Rotzinger, M. K. Nazeeruddin, et al., "Preparation of phosphonated polypyridyl ligands to anchor transition-metal complexes on oxide surfaces: application for the conversion of light to electricity with nanocrystalline $\mathrm{TiO}_{2}$ films," Chemical Communications, pp. 65-66, 1995.

[50] F. Kong, S. Dai, and K. Wang, "Dye sensitizers used in dyesensitized solar cells," Huaxue Tongbao, vol. 68, no. 5, pp. 338345, 2005.

[51] O. Kohle, S. Ruile, and M. Grätzel, "Ruthenium(II) charge-transfer sensitizers containing 4, 4'-dicarboxy2,2 $2^{\prime}$-bipyridine. synthesis, properties, and bonding mode of coordinated thio-and selenocyanates," Inorganic Chemistry, vol. 35, no. 16, pp. 4779-4787, 1996.

[52] K. Sayama, S. Tsukagoshi, K. Hara, et al., "Photoelectrochemical properties of J aggregates of benzothiazole merocyanine dyes on a nanostructured $\mathrm{TiO}_{2}$ film," Journal of Physical Chemistry B, vol. 106, no. 6, pp. 1363-1371, 2002.

[53] K. Hara, K. Sayama, Y. Ohga, A. Shinpo, S. Suga, and H. Arakawa, "A coumarin-derivative dye sensitized nanocrystalline $\mathrm{TiO}_{2}$ solar cell having a high solar-energy conversion efficiency up to 5.6\%," Chemical Communications, no. 6, pp. 569-570, 2001.

[54] K. Hara, Z.-S. Wang, T. Sato, et al., "Oligothiophenecontaining coumarin dyes for efficient dye-sensitized solar cells," Journal of Physical Chemistry B, vol. 109, no. 32, pp. 15476-15482, 2005.

[55] K. Hara, M. Kurashige, Y. Dan-Oh, et al., "Design of new coumarin dyes having thiophene moieties for highly efficient organic-dye-sensitized solar cells," New Journal of Chemistry, vol. 27, no. 5, pp. 783-785, 2003.

[56] Z. S. Wang, Y. Cui, K. Hara, et al., "High efficiencylight-harvesting coumarin dyes for efficient and stable dyesensitized solar cells," in The 16th International Conference of Photochemical Conversion and Solar Storage, Uppsala, Sweden, July 2006, W4-P-95.

[57] T. Kitamura, M. Ikeda, K. Shigaki, et al., "Phenyl-conjugated oligoene sensitizers for $\mathrm{TiO}_{2}$ solar cells," Chemistry of Materials, vol. 16, no. 9, pp. 1806-1812, 2004.

[58] K. Hara, M. Kurashige, S. Ito, et al., "Novel polyene dyes for highly efficient dye-sensitized solar cells," Chemical Communications, no. 2, pp. 252-253, 2003.

[59] S.-L. Li, K.-J. Jiang, K.-F. Shao, and L.-M. Yang, "Novel organic dyes for efficient dye-sensitized solar cells," Chemical Communications, no. 26, pp. 2792-2794, 2006.

[60] T. Horiuchi, H. Miura, K. Sumioka, and S. Uchida, "High efficiency of dye-sensitized solar cells based on metal-free indoline dyes," Journal of the American Chemical Society, vol. 126, no. 39, pp. 12218-12219, 2004.

[61] S. Ito, S. M. Zakeeruddin, R. Humphry-Baker, et al., "Highefficiency organic-dye-sensitized solar cells controlled by nanocrystalline- $\mathrm{TiO}_{2}$ electrode thickness," Advanced Materials, vol. 18, no. 9, pp. 1202-1205, 2006.

[62] Z.-S. Wang, F.-Y. Li, and C.-H. Huang, "Photocurrent enhancement of hemicyanine dyes containing $\mathrm{RSO}_{3}^{-}$group through treating $\mathrm{TiO}_{2}$ films with hydrochloric acid," Journal of Physical Chemistry B, vol. 105, no. 38, pp. 9210-9217, 2001.

[63] W. Zhao, B. W. Zhang, Y. Cao, X. Xiao, and R. Yang, "Photoelectric conversion performance of nanocrystalline $\mathrm{TiO}_{2}$ film electrodes modified with squarylium cyanine functional materials," Journal of Functional Materials, vol. 30, no. 3, pp. 304306, 1999. 
[64] W. Zhao, Y. J. Hou, X. S. Wang, et al., "Study on squarylium cyanine dyes for photoelectric conversion," Solar Energy Materials and Solar Cells, vol. 58, no. 2, pp. 173-183, 1999.

[65] C. Shi, S. Dai, K. Wang, X. Pan, F. Kong, and L. Hu, "The adsorption of 4-tert-butylpyridine on the nanocrystalline $\mathrm{TiO}_{2}$ and Raman spectra of dye-sensitized solar cells in situ," Vibrational Spectroscopy, vol. 39, no. 1, pp. 99-105, 2005.

[66] C.-W. Shi, S.-Y. Dai, K.-J. Wang, et al., "Application of 3-hexyl1-methylimidazolium iodide to dye-sensitized solar cells," Acta Chimica Sinica, vol. 63, no. 13, pp. 1205-1209, 2005.

[67] C. Shi, S. Dai, K. Wang, et al., "Influence of various cations on redox behavior of $\mathrm{I}^{-}$and $\mathrm{I}_{3}^{-}$and comparison between KI complex with 18-crown-6 and 1,2-dimethyl-3-propylimidazolium iodide in dye-sensitized solar cells," Electrochimica Acta, vol. 50, no. 13, pp. 2597-2602, 2005.

[68] C.-W. Shi, S.-Y. Dai, K.-J. Wang, et al., " $\mathrm{I}_{3}^{-} / \mathrm{I}^{-}$redox behavior of alkali-metal iodide complexes with crown ether/cryptand macrocycles and their applications to dye-sensitized solar cells," Chinese Journal of Chemistry, vol. 23, no. 3, pp. 251-254, 2005.

[69] Z.-S. Wang, K. Sayama, and H. Sugihara, "Efficient eosin Y dye-sensitized solar cell containing $\mathrm{Br}^{-} / \mathrm{Br}_{3}^{-}$electrolyte," Journal of Physical Chemistry B, vol. 109, no. 47, pp. 22449-22455, 2005.

[70] B. V. Bergeron, A. Marton, G. Oskam, and G. J. Meyer, "Dyesensitized $\mathrm{SnO}_{2}$ electrodes with iodide and pseudohalide redox mediators," Journal of Physical Chemistry B, vol. 109, no. 2, pp. 937-943, 2005.

[71] G. Oskam, B. V. Bergeron, G. J. Meyer, and P. C. Searson, "Pseudohalogens for dye-sensitized $\mathrm{TiO}_{2}$ photoelectrochemical cells," Journal of Physical Chemistry B, vol. 105, no. 29, pp. 6867-6873, 2001.

[72] S. A. Sapp, C. M. Elliott, C. Contado, S. Caramori, and C. A. Bignozzi, "Substituted polypyridine complexes of cobalt (II/III) as efficient electron-transfer mediators in dyesensitized solar cells," Journal of the American Chemical Society, vol. 124, no. 37, pp. 11215-11222, 2002.

[73] W. Kubo, T. Kitamura, K. Hanabusa, Y. Wada, and S. Yanagida, "Quasi-solid-state dye-sensitized solar cells using room temperature molten salts and a low molecular weight gelator," Chemical Communications, no. 4, pp. 374-375, 2002.

[74] H. Paulsson, A. Hagfeldt, and L. Kloo, "Molten and solid trialkylsulfonium iodides and their polyiodides as electrolytes in dye-sensitized nanocrystalline solar cells," Journal of Physical Chemistry B, vol. 107, no. 49, pp. 13665-13670, 2003.

[75] P. Wang, S. M. Zakeeruddin, J.-E. Moser, R. Humphry-Baker, and M. Grätzel, "A solvent-free, $\mathrm{SeCN}^{-} /(\mathrm{SeCN})_{3}^{-}$based ionic liquid electrolyte for high-efficiency dye-sensitized nanocrystalline solar cells," Journal of the American Chemical Society, vol. 126, no. 23, pp. 7164-7165, 2004.

[76] P. Wang, S. M. Zakeeruddin, J.-E. Moser, and M. Grätzel, “A new ionic liquid electrolyte enhances the conversion efficiency of dye-sensitized solar cells," Journal of Physical Chemistry B, vol. 107, no. 48, pp. 13280-13285, 2003.

[77] P. Wang, S. M. Zakeeruddin, P. Comte, I. Exnar, and M. Grätzel, "Gelation of ionic liquid-based electrolytes with silica nanoparticles for quasi-solid-state dye-sensitized solar cells," Journal of the American Chemical Society, vol. 125, no. 5, pp. 1166-1167, 2003.

[78] P. Wang, S. M. Zakeeruddin, R. Humphry-Baker, and M. Grätzel, "A binary ionic liquid electrolyte to achieve $\geq 7 \%$ power conversion efficiencies in dye-sensitized solar cells," Chemistry of Materials, vol. 16, no. 14, pp. 2694-2696, 2004.
[79] D. Kuang, P. Wang, S. Ito, S. M. Zakeeruddin, and M. Grätzel, "Stable mesoscopic dye-sensitized solar cells based on tetracyanoborate ionic liquid electrolyte," Journal of the American Chemical Society, vol. 128, no. 24, pp. 7732-7733, 2006.

[80] N. Mohmeyer, D. Kuang, P. Wang, H.-W. Schmidt, S. M. Zakeeruddin, and M. Grätzel, "An efficient organogelator for ionic liquids to prepare stable quasi-solid-state dye-sensitized solar cells," Journal of Materials Chemistry, vol. 16, no. 29, pp. 2978-2983, 2006.

[81] R. Kawano, H. Matsui, C. Matsuyama, et al., "High performance dye-sensitized solar cells using ionic liquids as their electrolytes," Journal of Photochemistry and Photobiology A, vol. 164, no. 1-3, pp. 87-92, 2004.

[82] F. Mazille, Z. Fei, and D. Kuang, "Influence of ionic liquids bearing functional groups in dye-sensitized solar cells," Inorganic Chemistry, vol. 45, no. 4, pp. 1585-1590, 2006.

[83] H. Matsui, K. Okada, T. Kawashima, et al., "Application of an ionic liquid-based electrolyte to a to a $100 \mathrm{~mm} \times 100 \mathrm{~mm}$ sized dye-sensitized solar cell," Journal of Photochemistry and Photobiology A, vol. 164, no. 1-3, pp. 129-135, 2004.

[84] P. Wang, S. M. Zakeeruddin, I. Exnar, and M. Grätzel, "High efficiency dye-sensitized nanocrystalline solar cells based on ionic liquid polymer gel electrolyte," Chemical Communications, vol. 8, no. 24, pp. 2972-2973, 2002.

[85] V. Jovanovski, E. Stathatos, B. Orel, and P. Lianos, "Dye-sensitized solar cells with electrolyte based on a trimethoxysilane-derivatized ionic liquid," Thin Solid Films, vol. 511-512, pp. 634-637, 2006.

[86] K. Suzuki, M. Yamaguchi, M. Kumagai, N. Tanabe, and S. Yanagida, "Dye-sensitized solar cells with ionic gel electrolytes prepared from imidazolium salts and agarose," Comptes Rendus Chimie, vol. 9, no. 5-6, pp. 611-616, 2006.

[87] H. Usui, H. Matsui, N. Tanabe, and S. Yanagida, "Improved dye-sensitized solar cells using ionic nanocomposite gel electrolytes," Journal of Photochemistry and Photobiology A, vol. 164, no. 1-3, pp. 97-101, 2004.

[88] R. Sastrawan, J. Beier, U. Belledin, et al., "A glass frit-sealed dye solar cell module with integrated series connections," Solar Energy Materials and Solar Cells, vol. 90, no. 11, pp. 1680-1691, 2006.

[89] G. R. A. Kumara, S. Kaneko, M. Okuya, and K. Tennakone, "Fabrication of dye-sensitized solar cells using triethylamine hydrothiocyanate as a CuI crystal growth inhibitor," Langmuir, vol. 18, no. 26, pp. 10493-10495, 2002.

[90] Q.-B. Meng, K. Takahashi, X.-T. Zhang, et al., "Fabrication of an efficient solid-state dye-sensitized solar cell," Langmuir, vol. 19, no. 9, pp. 3572-3574, 2003.

[91] U. Bach, D. Lupo, P. Comte, et al., "Solid-state dye-sensitized mesoporous $\mathrm{TiO}_{2}$ solar cells with high photon-to-electron conversion efficiencies," Nature, vol. 395, no. 6702, pp. 583$585,1998$.

[92] J. Kang, W. Li, X. Wang, Y. Lin, X. Xiao, and S. Fang, "Polymer electrolytes from PEO and novel quaternary ammonium iodides for dye-sensitized solar cells," Electrochimica Acta, vol. 48, no. 17, pp. 2487-2491, 2003.

[93] Y. Ren, Z. Zhang, S. Fang, M. Yang, and S. Cai, "Application of PEO based gel network polymer electrolytes in dye-sensitized photoelectrochemical cells," Solar Energy Materials and Solar Cells, vol. 71, no. 2, pp. 253-259, 2002.

[94] L. Wang, S. Fang, Y. Lin, X. Zhou, and M. Li, "A 7.72\% efficient dye sensitized solar cell based on novel necklace-like polymer gel electrolyte containing latent chemically cross-linked gel electrolyte precursors," Chemical Communications, no. 45, pp. 5687-5689, 2005. 
[95] F. Cao, G. Oskam, and P. C. Searson, "A solid state, dye sensitized photoelectrochemical cell," Journal of Physical Chemistry, vol. 99, no. 47, pp. 17071-17073, 1995.

[96] J. Wu, Z. Lan, D. Wang, et al., "Gel polymer electrolyte based on poly (acrylonitrile-co-styrene) and a novel organic iodide salt for quasi-solid state dye-sensitized solar cell," Electrochimica Acta, vol. 51, no. 20, pp. 4243-4249, 2006.

[97] L. Guo, S.-Y. Dai, K.-J. Wang, X.-Q. Fang, C.-W. Shi, and X. $\mathrm{Pan}$, "Dye-sensitized nano- $\mathrm{TiO}_{2}$ thin memberane solar cells based on P(VDF-HFP)-type gel electrolytes," Chemical Journal of Chinese Universities, vol. 26, no. 10, pp. 1934-1937, 2005.

[98] S. Dai, J. Weng, Y. Sui, et al., "The design and outdoor application of dye-sensitized solar cells," to be available online in Inorganica Chimica Acta. 

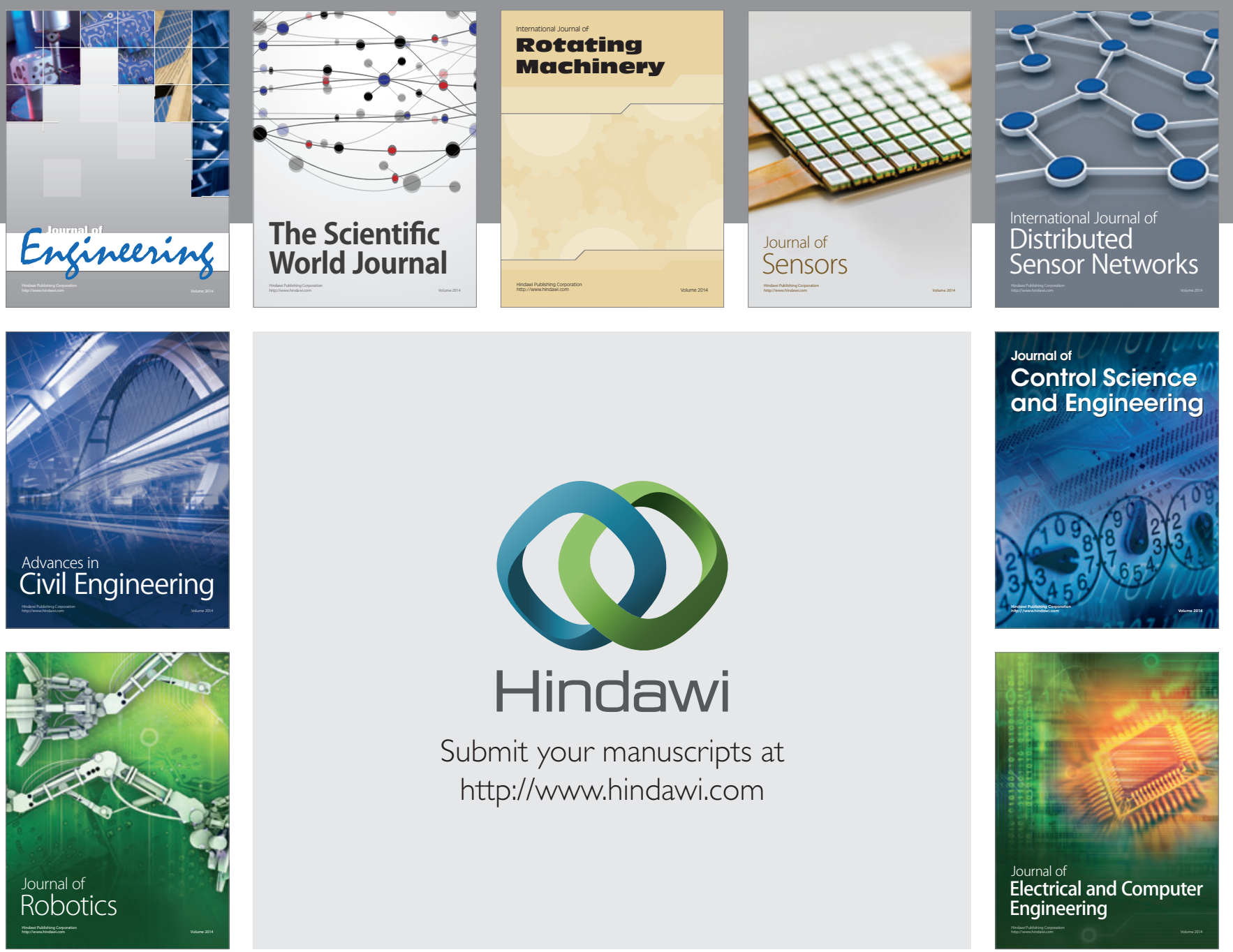

Submit your manuscripts at

http://www.hindawi.com
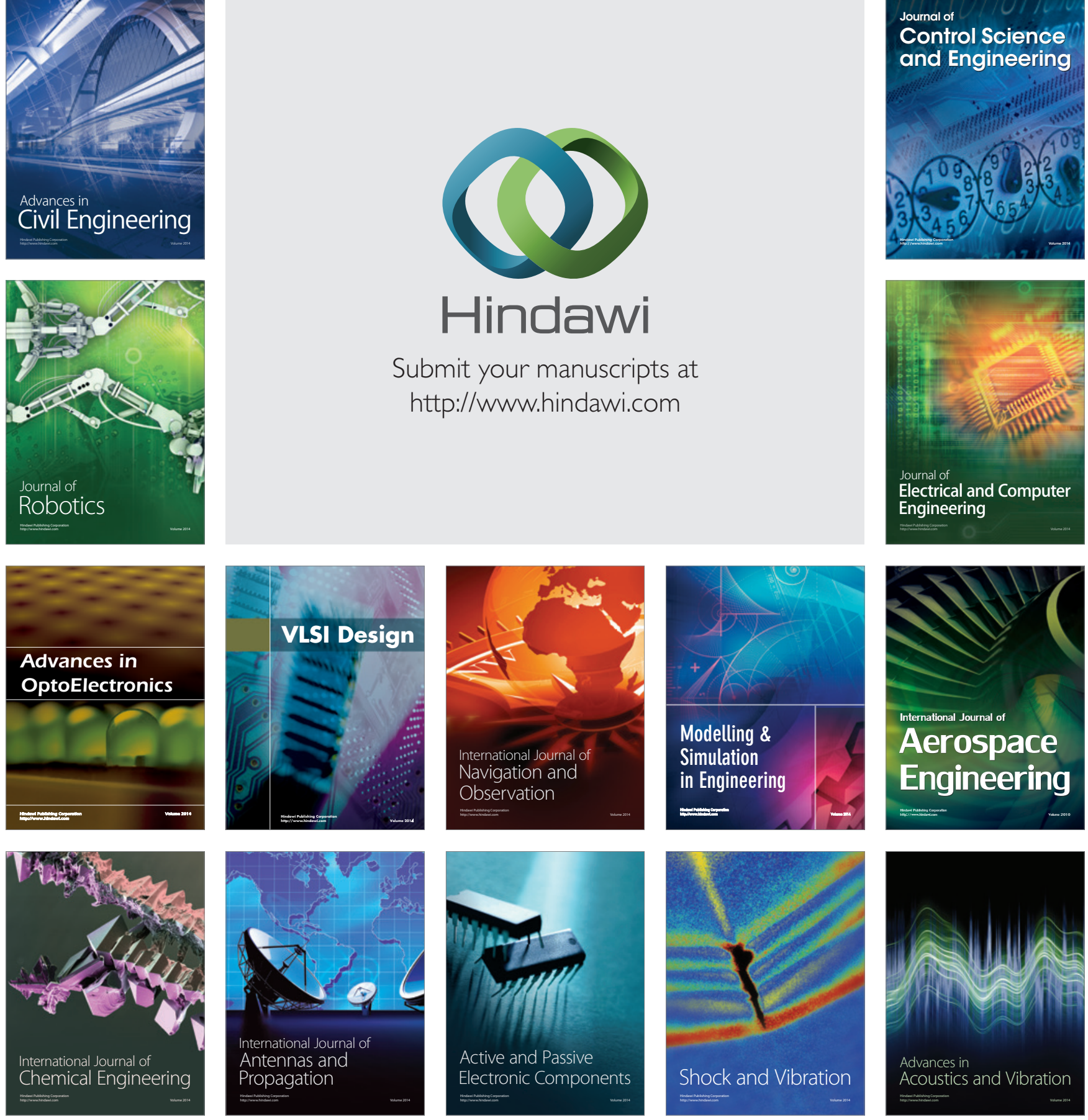